\title{
Evaluation of the cytotoxicity (HepG2) and chemical composition of polar extracts from the ruderal species Coleostephus myconis (L.) Rchb.f.
}

Sílvia M. F. Bessada, João C. M. Barreira, J. Santos, Carla Costa, Filipa B. Pimentel, Maria João Bessa, João Paulo Teixeira \& M.Beatriz P.P. Oliveira

To cite this article: Sílvia M. F. Bessada, João C. M. Barreira, J. Santos, Carla Costa, Filipa B. Pimentel, Maria João Bessa, João Paulo Teixeira \& M.Beatriz P.P. Oliveira (2017) Evaluation of the cytotoxicity (HepG2) and chemical composition of polar extracts from the ruderal species Coleostephus myconis (L.) Rchb.f., Journal of Toxicology and Environmental Health, Part A, 80:13-15, 641-650, DOI: 10.1080/15287394.2017.1286915

To link to this article: https://doi.org/10.1080/15287394.2017.1286915

\section{曲 Published online: 19 May 2017.}

\section{Submit your article to this journal $\llbracket$}

Щ Article views: 48

Q View related articles ¿

View Crossmark data $\asymp$ 


\title{
Evaluation of the cytotoxicity (HepG2) and chemical composition of polar extracts from the ruderal species Coleostephus myconis (L.) Rchb.f.
}

\author{
Sílvia M. F. Bessada ${ }^{a}$, João C. M. Barreira ${ }^{a, b}$, J. Santos ${ }^{a}$, Carla Costac,d, Filipa B. Pimentel ${ }^{a}$, Maria João Bessa ${ }^{c, d}$, \\ João Paulo Teixeirac,d, and M.Beatriz P.P. Oliveira ${ }^{\mathrm{a}}$ \\ aREQUIMTE/LAQV,Department of Chemical Sciences, Faculty of Pharmacy, University of Porto, Porto, Portugal; ' ${ }^{b} \mathrm{CIMO}$-ESA, Instituto \\ Politécnico de Bragança, Bragança, Portugal; 'Department of Environmental Health, Portuguese National Institute of Health, Porto, Portugal; \\ dEPIUnit - Institute of Public Health, University of Porto, Porto, Portugal
}

\begin{abstract}
Coleostephus myconis (L.) Rchb.f. (Asteraceae) is a highly disseminated plant species with ruderal and persistent growth. Owing to its advantageous agronomic properties, C. myconis might have industrial applications. However, this species needs to be comprehensively characterized before any potential use. In a previous study, the phenolic composition and antioxidant activity of different $C$. myconis tissues were characterized. This investigation was extended to examine the cytotoxic potential of selected plant tissues (flowers and green parts) using a HepG2 cell line by utilizing the lysosomal neutral red uptake assay or mitochondrial (3-(4,5-dimethylthiazolyl-2)-2,5diphenyltetrazolium bromide assay. In addition, the macronutrients content, lipophilic compounds (fatty acids, tocopherols), and amino acids were also determined. C. myconis flowers were used in the senescence stage, which was previously identified as the stage that presented maximal phenolic content and highest antioxidant activity. In contrast, stems and leaves were employed due to their high biomass proportion. Regarding cytotoxicity, mitochondrial and lysosomal damage was only significant when HepG2 cells were exposed to the highest extract concentrations (stems and leaves, $0.9 \mathrm{mg} / \mathrm{ml}$; senescent flowers, $0.3 \mathrm{mg} / \mathrm{ml}$ ). Chemically, the senescent flowers were mostly characterized by their high levels of fat, amino acids (especially threonine), oleic acid, $\beta$-, and $\gamma$-tocopherol, while stems and leaves contained high concentrations of carbohydrates, linolenic acid, and a-tocopherol. In general, these results provide information regarding the threshold concentrations of $C$. myconis extracts that might be used in different applications without toxicity hazards.
\end{abstract}

\section{Introduction}

Natural medicinal plants are used by the majority of the world's population (Bernal et al., 2011) and these so-called phytomedicines are playing an increasing greater role in human health care. Medicinal plants are emerging as a strong alternative to synthetic products, not only in traditional medicine but also in a number of food and pharmaceutical products due to their nutritional properties and bioactivity (Krishnaiah et al., 2011; Bessada et al., 2015). Further, medicinal plants may provide beneficial health effects due to the presence of different bioactive compounds and nutraceuticals (Dias et al., 2014).

Coleostephus myconis (L.) Rchb.f. (family Asteraceae) is a species with ruderal growth and persistence in abandoned soils, known for its plentiful yellow flowering between March and August. Bessada et al. (2015) noted that Asteraceae species possessed potential to act as a source of bioactive compounds with application in medicine, pharmaceutical, cosmetic, and food industries. However, and despite their potential applications and uses in traditional medicine (e.g., in the treatment of gastrointestinal and liver disorders and malaria), there are few studies regarding the effectiveness and safety of Asteraceae species. Therefore, evaluating the potential toxicity of these plant extracts, particularly their cytotoxicity and genotoxicity, needs to be considered (Franco et al., 2015).

C. myconis was previously characterized for its phenolic profile and antioxidant activity in different extracts obtained from the green parts (stems and leaves) and flowers at different ripening

CONTACT João C. M. Barreira jbarreira@ipb.pt @ REQUIMTE/LAQV, Department of Chemical Sciences, Faculty of Pharmacy, University of Porto, Rua Jorge Viterbo Ferreira, no 228, 4050-313 Porto, Portugal.

๑) 2017 Taylor \& Francis 
stages. The highest antioxidant activity and phenolic content was detected in senescent flowers, particularly those obtained from the hydro-ethanolic extracts (Bessada et al., 2016). However, the cytotoxic potential of hydro-ethanolic extracts of C. myconis senescent flowers and green parts remains to be evaluated in a HepG2 (human hepatocellular carcinoma) cell line, which is a reference cell line for toxicity evaluation (Ju et al., 2015). In addition, the same botanical tissues were characterized regarding their macronutrient composition, lipophilic compounds (fatty acids [FA] and tocopherols), and amino acids composition.

\section{Materials and Methods}

\section{Standards and Reagents}

All chemicals and solvents were of analytical grade and purchased from common sources. Tocol (2-methyl-2-(4,8,12-trimethyl-tridecyl)-chroman6-ol) was purchased from Matreya Inc. (Pennsylvania, USA). The mixture of methyl esters of FA standards (FAME) Supelco37 was obtained from Supelco (Bellefonte, PA, USA), while the mixture of L-amino acids LAA21 and norleucine was acquired from Sigma (St. Louis, MO, USA). For the chromatographic analysis, acetonitrile (high-performance liquid chromatography [HPLC] grade) was obtained from Merck KGaA (Darmstadt, Germany). Neutral red dye, 3-(4,5dimethylthiazolyl-2)-2,5-diphenyltetrazolium bromide (MTT), and Triton X-100 were purchased from Sigma-Aldrich Co. Dimethyl sulfoxide, acetic acid (glacial) 100\%, and ethanol absolute were bought from Merck KGaA. The HepG2 cell line was obtained from European Collection of Cell Cultures. Cell culture media components were all Invitrogen $^{\mathrm{nx}}$ and acquired from Thermo Fisher Scientific Inc. Water was obtained from a Milli-Q water purification system (TGI Pure Water Systems, USA).

\section{Samples}

After taxonomical identification, C. myconis plants were collected in the Northwest of Portugal (Riba de Mouro, Minho) in June, 2014, and further divided into green parts (stems and leaves) and flowers. For each plant part, three independent samples were used; each of the samples was further analyzed thrice. The vegetal material was then frozen, lyophilized $\left(48 \mathrm{~h},-78^{\circ} \mathrm{C}, 0.015 \mathrm{mbar}\right)$ (Telstar Cryodos-80, Terrassa, Barcelona), reduced to powder and mixed to obtain homogenized samples, and stored in plastic tubes at room temperature for subsequent use.

\section{Macronutrients Analysis}

Macronutrients were analyzed following the Association of Analytical Communities methods (AOAC, 2012). Moisture content was instrumentally determined using an infrared moisture analyzer (SMO 01, Scaltec Instruments, Heiligenstadt, Germany). Ash content was determined by incinerating the sample in a muffle furnace at $550^{\circ} \mathrm{C}$. Protein content $(N \times 6.25)$ was determined using the Kjeldahl procedure. Total fat was determined by Soxhlet extraction with petroleum ether. Total carbohydrate content was determined by difference. Energy was calculated according to the general Atwater factors (Atwater \& Benedict, 1902): Energy $(\mathrm{kcal})=4 \times(\mathrm{g}$ protein $)+3.75 \times(\mathrm{g}$ carbohydrate $)+9 \times(\mathrm{g}$ fat $)$. The results were expressed as $\mathrm{g} / 100 \mathrm{~g}$ of dry mass $(\mathrm{dm})$.

\section{Amino Acids Profile}

The amino acids histidine (His), arginine (Arg), aspartic acid + glutamic acid (Asp + Glu), threonine (Thr), glycine (Gly), alanine (Ala), proline (Pro), valine + methionine $(\mathrm{Val}+\mathrm{Met})$, phenylalanine (Phe), isoleucine (Ile), leucine (Leu), lysine (Lys), and tyrosine (Tyr) were analyzed by HPLC using a fluorescence detector (FD), after subjecting the samples to acidic hydrolysis $\left(\mathrm{HCl} 6 \mathrm{~mol} / \mathrm{l}, 110^{\circ}\right.$ $\mathrm{C}, 24 \mathrm{~h}$ ) and derivatization with dansyl chloride (Rodrigues et al., 2015).

The chromatographic analysis was carried out in an integrated HPLC system (Jasco, Tokyo, Japan), equipped with two Jasco PU-980 Plus HPLC pumps, an AS-2057 Plus automated injector $(20 \mu \mathrm{l}$ loop), and a FP-2020 Plus FD, programmed for excitation at $335 \mathrm{~nm}$ and emission at $514 \mathrm{~nm}$. The compounds separation was achieved in a reversed-phase column (Luna $5 \mathrm{u}$ C18, $4.6 \times 250 \mathrm{~mm}, 5 \mu \mathrm{m})$ from Phenomenex 
(Torrance, CA, USA), operating at a controlled temperature of $40^{\circ} \mathrm{C}$ (Jones Chromatography, San Diego, Ca, USA). Chromatographic data were analyzed using the JASCO-Chrom NAV Chromatography Software (Jasco, Japan). The amino acids were identified by retention time comparison with authentic standards and confirmed by spiking the standards into the C. myconis samples. Quantification was carried out on the basis of the internal standard method (norleucine). Analyses were performed in triplicate and results were expressed in $\mathrm{mg} / \mathrm{g}$ of dry powder.

\section{FA Profile}

The FAME were obtained by cold transmethylation with methanolic potassium hydroxide (Commission Regulation, 2002). The derivatization process was initiated by mixing $40 \mu \mathrm{l}$ extracted oil, $3 \mathrm{ml}$ hexane, and $200 \mu \mathrm{l}$ methanolic potassium hydroxide (2 M). After vortexing (1 $\mathrm{min}$ ), $500 \mathrm{mg}$ of $\mathrm{Na}_{2} \mathrm{SO}_{4}$ was added to eliminate any remaining water. This mixture was further vortexed and centrifuged (2500g, $5 \mathrm{~min}$, Heraeus Sepatech Labofugue Ae, Heraeus Instruments, Hanau, Germany). The supernatant was then transferred to a glass vial and analyzed by gas chromatography in a Shimadzu GC-2010 Plus gas chromatograph equipped with a split-splitless injector, a flame ionization detector detector and an auto-sampler Shimadzu AOC-20i (Shimadzu, Tokyo, Japan). A CPSil 88 fused silica capillary column (Varian, Middelburg, Netherlands; $50 \mathrm{~m}$ $\times 0.25 \mathrm{~mm}$ i.d., $0.19 \mu \mathrm{m}$ film thickness) was used. Helium was used as carrier gas $(120 \mathrm{kPa})$ and separation was achieved with the following temperature program: $5 \mathrm{~min}$ at $140^{\circ} \mathrm{C}$, followed by an increase of $5^{\circ} \mathrm{C} / \mathrm{min}$ from 140 to $220^{\circ} \mathrm{C}$ and maintained at $220^{\circ} \mathrm{C}$ for $15 \mathrm{~min}$. The temperature of injector and detector was 250 and $270^{\circ} \mathrm{C}$, respectively; a split ratio of 1:50 was used and the injection volume was $1 \mu$ l. Each FAME was identified by direct comparison with a standard mixture (FAME 37, Supelco, Bellefonte, PA, USA) and analyzed using the Shimadzu software GC Solution (v. 2.30, Shimadzu GC Solution, Shimadzu, Tokyo, Japan) based on the relative peak areas. The analyses were done in duplicate and the results expressed in relative \% each FA, based on the relative peak areas.

\section{Vitamin E Composition}

For identification and quantification of individual compounds, standard solutions of $\alpha^{-}, \beta-, \gamma^{-}$, and $\delta$-tocopherol and $\alpha$-, $\beta$-, $\gamma^{-}$, and $\delta$-tocotrienol were prepared in $n$-hexane $(25,18.75,12.5,6.25,2.5$, and $1.25 \mathrm{mg} / \mathrm{ml}$ ). Each of these solutions contained $20 \mu \mathrm{l}$ of tocol (internal standard, $1 \mathrm{mg} /$ $\mathrm{ml})$. The lipid fraction for tocopherols quantification was obtained by Soxhlet extraction with petroleum ether $(1.5 \mathrm{~h})$. The extraction was performed in sample aliquots of approximately 5 g, previously spiked with the internal standard (10 $\mu 11 \mathrm{mg} / \mathrm{ml}$ tocol solution). The chromatographic analysis was carried out in an HPLC integrated system equipped with an AS-2057 automated injector, a PU-2089 pump, a MD-2018 multiwavelength diode array detector, and a FP-2020 FD (Jasco, Tokyo, Japan), programmed for excitation at $290 \mathrm{~nm}$ and emission at $330 \mathrm{~nm}$ (Rodrigues et al., 2015). The chromatographic separation of the compounds was achieved on a normal phase Supelcosil $^{\mathrm{Tm}}$ LC-SI $(3 \mu \mathrm{m} ; 75 \mu \mathrm{mm} \times 3.0 \mathrm{~mm}$; Supelco, Bellefonte, PA, USA). Chromatographic data were analyzed using JASCO-Chrom NAV Chromatography Software. The compounds were identified based on their UV/vis spectra and the respective patterns retention time. Quantification was based on the fluorescence signal response of each standard, converted to concentration units through calibration curves obtained from commercial standards of each compound, using the internal standard method. The results were expressed in $\mu \mathrm{g} / \mathrm{g}$ of fat.

\section{Cytotoxicity Evaluation}

\section{Preparation of Different C. Myconis Hydro-Ethanolic Extracts}

Lyophilized samples of (1) senescent flowers and (2) green parts $(0.5 \mathrm{~g})$ were submitted to solvent extraction (50 $\mathrm{ml}$ ethanol:water, 1:1) by magnetic stirring $\left(1 \mathrm{~h}, 25^{\circ} \mathrm{C}, 150 \mathrm{rpm}\right)$. Extracts were filtered through Whatman No.1 paper. The obtained residues were re-extracted under the same conditions. The combined hydro-ethanolic extracts were dried 
using a rotary evaporator (Rotavapor R-210, Büchi, Flawil, Switzerland) under reduced pressure and further redissolved directly in the cell culture medium for cytotoxicity evaluation. The assayed concentrations were defined according to the results obtained in the antioxidant activity evaluated previously (Bessada et al., 2016).

\section{Cell Viability, Membrane Integrity, and Cell Recovery}

HepG2 cells were cultivated in DMEM (Dulbecco's modified Eagle's medium) medium with L-glutamine (1\%), antibiotic and antimycotic solution (1\%), supplemented with $10 \%$ heat-inactivated fetal bovine serum, in a humidified atmosphere with $5 \%$ $\mathrm{CO}_{2}\left(37^{\circ} \mathrm{C}\right)$. To carry out the experiments, 25,000 cells were seeded in 96-well plates (flat bottom) and allowed to adhere overnight at $37^{\circ} \mathrm{C}$.

The MTT assay (Mosmann, 1983) and neutral red uptake (NRU) assay (Borenfreund \& Puerner, 1985) were used to test potential cytotoxicity of $C$. myconis hydro-ethanolic extracts (senescent flowers and green parts) on HepG2 cells. In each assay, five different extract concentrations were used, defined from the average $\mathrm{EC}_{50}$ (effective concentration showing $50 \%$ of activity) values obtained in different antioxidant activity assays (Bessada et al., 2016): $\mathrm{EC}_{25}$ (stems and leaves, $0.30 \mathrm{mg} / \mathrm{ml}$; senescent flowers, $0.10 \mathrm{mg} / \mathrm{ml}$ ), $\mathrm{EC}_{37.5}$ (stems and leaves, $0.45 \mathrm{mg} / \mathrm{ml}$; senescent flowers, $0.15 \mathrm{mg} /$ $\mathrm{ml}$ ), $\mathrm{EC}_{50}$ (stems and leaves, $0.60 \mathrm{mg} / \mathrm{ml}$; senescent flowers, $0.2 \mathrm{mg} / \mathrm{ml}$ ), $\mathrm{EC}_{62.5}$ (stems and leaves, 0.75 $\mathrm{mg} / \mathrm{ml}$; senescent flowers, $0.25 \mathrm{mg} / \mathrm{ml}$ ), and $\mathrm{EC}_{75}$ (stems and leaves, $0.90 \mathrm{mg} / \mathrm{ml}$; senescent flowers, $0.3 \mathrm{mg} / \mathrm{ml}$ ). In addition, two sequential exposure times (24 and $48 \mathrm{~h}$ ) were evaluated. Negative (medium without extracts) and positive controls (Triton X-100, 1\%) were also assayed. Absorbance was measured at $595 \mathrm{~nm}$ (MTT) or $540 \mathrm{~nm}$ (NRU) using a Cambrex ELx808 microplate reader (Biotek, KC4). To determine whether cells treated with $C$. myconis extracts recovered their proliferative capacity after removal of extracts, the cell recovery assay was used. After 24 and 48 h exposure to extracts, these were removed, and fresh cell culture medium was added to cells and incubated further for $24 \mathrm{~h}$. The degree of cell recovery was determined using MTT and NRU assays (with the same procedure mentioned above).
A parallel set of experiments conducted without cells was carried out to exclude the potential interaction of the extracts with the dyes used in MTT and NRU assays. Data obtained demonstrated no interaction between the tested extracts and the dyes used for cytotoxicity assessment. A minimum of three independent experiments (three replicates were analyzed in each experiment) were performed for each experimental condition tested.

\section{Statistical Analysis}

Results are expressed as mean \pm standard deviation. An analysis of variance followed by Tukey's test (homoscedastic distributions) or Tamhane's T2 test (heteroscedastic distributions was used to classify the statistical differences in cell viability resulting from the exposure to different extract concentrations). The homogeneity of variance was tested by means of the Levene's test. Cytotoxicity data were further analyzed by evaluating Spearman's correlation (associations between concentration and cell viability values).

Principal components analysis (PCA), a pattern recognition unsupervised classification method, was applied to identify the chemical and cytotoxic features that best characterize each assayed botanical tissue. The number of dimensions to keep for data analysis was assessed by the respective eigenvalues (which should be greater than one), by the Cronbach's alpha parameter (that must be positive), and also by total percentage of variance (that should be as high as possible) explained by the number of components selected. The number of plotted dimensions (two) was selected in order to allow meaningful interpretations.

All the abovementioned statistical tests were performed considering $\alpha=0.05$, using the Statistical Package for Social Sciences, v. 22.0. Nonlinear regression fitting of the dose-response curve to the Hill equation was performed to derive the in vitro cytotoxicity $\mathrm{IC}_{50}$ (i.e., concentration at which cell viability was inhibited by $50 \%$ ), using PRISM 6.0 (GraphPad Software, Inc.).

\section{Results}

The chemical characterization and evaluation of the nutritional profile of a wild plant, broadly 
available and easy to obtain, constitute a fundamental requisite considering its potential use in several applications. Accordingly, the macronutrients, amino acids, FA, and tocopherols profiles were characterized in different botanical tissues of C. myconis.

\section{Nutritional and Chemical Composition}

Considering fresh mass basis, both studied components, stems and leaves and senescent flowers, presented high moisture values: $79.8 \%$ and $75.1 \%$, respectively (Table 1 ). In $\mathrm{dm}$ basis, carbohydrates were the major macronutrient found in both cases $(81.1 \mathrm{~g} / 100 \mathrm{~g} \mathrm{dm}$ in senescent flowers; $87.6 \mathrm{~g} / 100 \mathrm{~g} \mathrm{dm}$ in stems and leaves). The protein contents were relatively high, especially in the senescent flowers ( $8.3 \mathrm{~g} /$ $100 \mathrm{~g} \mathrm{dm}$ ), which also showed significantly higher fat $(3.6 \mathrm{~g} / 100 \mathrm{~g} \mathrm{dm})$ levels than those measured in the green parts. On the other hand, ash quantities were similar in both C. myconis parts $(6.5 \mathrm{~g} / 100 \mathrm{~g} \mathrm{dm}$ stems and leaves; $7.0 \mathrm{~g} / 100 \mathrm{~g} \mathrm{dm}$ senescent flowers).

A total of eight essential amino acids (EAA) (threonine, phenylalanine, isoleucine, leucine, lysine, valine, and methionine) and seven non EAA (arginine, aspartate, glutamate, glycine, alanine, proline, and tyrosine) were detected in both botanical parts of C. myconis (Table 2). All the quantified amino acids were present in higher levels in the stems and leaves, in comparison to senescent flowers. Threonine was the predominant amino acid in both cases $(15 \mathrm{mg} / \mathrm{g} \mathrm{dm}$ senescent flowers, $6.2 \mathrm{mg} / \mathrm{g}$ $\mathrm{dm}$ stems and leaves), followed by the acidic amino acids (aspartate + glutamate: $8.7 \mathrm{mg} / \mathrm{g} \mathrm{dm}$ in senescent flowers, $3.1 \mathrm{mg} / \mathrm{g} \mathrm{dm}$ stems and leaves), lysine $(7.5 \mathrm{mg} / \mathrm{g} \mathrm{dm}$ senescent flowers, $4.0 \mathrm{mg} / \mathrm{g} \mathrm{dm}$ stems and leaves), and leucine $(6.2 \mathrm{mg} / \mathrm{g} \mathrm{dm}$ senescent flowers, $4.0 \mathrm{mg} / \mathrm{g} \mathrm{dm}$ stems and leaves).

Table 1. Macronutrients and Amino Acid Profiles and Energy Value C. myconis Stems and Leaves and Senescent Flowers.

\begin{tabular}{lcc}
\hline Component & Stems and leaves & Senescent flower \\
\hline Moisture $(\mathrm{g} / 100 \mathrm{~g} \mathrm{fm})$ & $79.8 \pm 0.2$ & $75.1 \pm 0.1$ \\
Fat $(\mathrm{g} / 100 \mathrm{~g} \mathrm{dm})$ & $1.4 \pm 0.1$ & $3.6 \pm 0.1$ \\
Protein $(\mathrm{g} / 100 \mathrm{~g} \mathrm{dm})$ & $4.4 \pm 0.3$ & $8.3 \pm 0.2$ \\
Ash $(\mathrm{g} / 100 \mathrm{~g} \mathrm{dm})$ & $6.6 \pm 0.1$ & $7.0 \pm 0.1$ \\
Carbohydrates $(\mathrm{g} / 100 \mathrm{~g} \mathrm{dm})$ & $87.6 \pm 0.4$ & $81.1 \pm 0.1$ \\
Energy $(\mathrm{kcal} / 100 \mathrm{~g} \mathrm{dm})$ & $359 \pm 1$ & $370 \pm 1$ \\
\hline
\end{tabular}

$\mathrm{fm}$ : Fresh mass; dm: dried mass.
Table 2. Amino Acids Profile ( $\mathrm{mg} / \mathrm{g}$ dry mass) in Stems and Leaves and Senescent Flowers of C. myconis.

\begin{tabular}{lcc}
\hline Amino acid & Stems and leaves & Senescent flowers \\
\hline Essential & & \\
$\quad$ Histidine & $0.45 \pm 0.05$ & $2.3 \pm 0.1$ \\
Threonine & $6.2 \pm 0.5$ & $15 \pm 1$ \\
Phenylalanine & $2.75 \pm 0.03$ & $3.5 \pm 0.2$ \\
Isoleucine & $2.15 \pm 0.04$ & $3.6 \pm 0.1$ \\
Leucine & $4.0 \pm 0.1$ & $6.2 \pm 0.2$ \\
Lysine & $4.0 \pm 0.1$ & $7.5 \pm 0.2$ \\
Valine + methionine & $1.91 \pm 0.03$ & $2.7 \pm 0.1$ \\
Nonessential & & \\
Arginine & $2.2 \pm 0.2$ & $3.3 \pm 0.1$ \\
Aspartate + glutamate & $3.1 \pm 0.1$ & $8.7 \pm 0.3$ \\
Glycine & $2.6 \pm 0.1$ & $4.7 \pm 0.1$ \\
Alanine & $2.7 \pm 0.4$ & $4.0 \pm 0.2$ \\
Proline & $2.25 \pm 0.04$ & $4.0 \pm 0.2$ \\
$\quad$ Tyrosine & $1.05 \pm 0.04$ & $2.5 \pm 0.2$ \\
\hline
\end{tabular}

The main FA found in senescent flowers were linoleic acid (C18:2n6c) (43\%), palmitic acid (C16:0) (21\%), and oleic acid (C18:1n9c) (15.3\%), while in stems and leaves, the most abundant forms were linolenic acid (C18:3n3) (51\%), followed by C18:2n6c (26\%) and C16:0 (16\%) (Table 3). Polyunsaturated fatty acids (PUFA) predominated in both C. myconis botanical parts (53\% of total FA in senescent flowers; $77 \%$ in stems and leaves). Monounsaturated fatty acids (MUFA) are present in less relevant \%: $15 \%$ in senescent flowers and 5\% in stems and leaves.

Regarding vitamin E profile, $\alpha-(74 \mu \mathrm{g} / \mathrm{g}$ oil $), \beta$ - (99 $\mu \mathrm{g} / \mathrm{g}$ oil $), \gamma$ - $(37 \mu \mathrm{g} / \mathrm{g}$ oil $)$, and $\delta$-tocopherol $(91 \mu \mathrm{g} / \mathrm{g}$ oil) isoforms were present in senescent flowers, while $\alpha$ - and $\delta$-tocopherol were the only isoforms in stems

Table 3. Fatty Acids Profile (Relative \%) in Stems and Leaves and Senescent Flowers of C. myconis.

\begin{tabular}{lcc}
\hline Fatty acid & Stems and leaves & Senescent flowers \\
\hline C10:0 & nd & $2.4 \pm 0.1$ \\
C12:0 & nd & $0.66 \pm 0.05$ \\
C14:0 & $0.39 \pm 0.03$ & $1.8 \pm 0.1$ \\
C15:0 & $0.13 \pm 0.01$ & $0.18 \pm 0.01$ \\
C16:0 & $16 \pm 1$ & $21 \pm 1$ \\
C16:1 & $1.00 \pm 0.03$ & nd \\
C18:0 & $1.5 \pm 0.1$ & $4.5 \pm 0.2$ \\
C18:1n9c & $4.5 \pm 0.5$ & $15.3 \pm 0.4$ \\
C18:2n6c & $26 \pm 1$ & $43 \pm 1$ \\
C18:3n3 & $51 \pm 1$ & $9.3 \pm 0.3$ \\
C20:0 & nd & $0.46 \pm 0.01$ \\
C22:0 & nd & $0.77 \pm 0.05$ \\
C23:0 & nd & $0.54 \pm 0.05$ \\
C20:5n3 & nd & $0.54 \pm 0.05$ \\
SFA & $18 \pm 1$ & $32 \pm 2$ \\
MUFA & $5 \pm 1$ & $15 \pm 1$ \\
PUFA & $77 \pm 2$ & $53 \pm 1$ \\
\hline
\end{tabular}

nd: Non-detected. 
Table 4. Tocopherols Profile ( $\mu \mathrm{g} / \mathrm{g}$ oil) in Stems and Leaves and Senescent Flowers of $C$. myconis.

\begin{tabular}{lcc}
\hline Vitamer & Stems and leaves & Senescent flowers \\
\hline a-Tocopherol & $110 \pm 14$ & $74 \pm 11$ \\
$\beta$-Tocopherol & nd & $99 \pm 10$ \\
$\gamma$-Tocopherol & nd & $37 \pm 10$ \\
$\delta$-Tocopherol & $215 \pm 5$ & $91 \pm 14$ \\
Tocopherols & $325 \pm 17$ & $165 \pm 22$ \\
\hline
\end{tabular}

nd: Non detected.

and leaves, in both cases in higher amounts ( $\alpha$-tocopherol: $110 \mu \mathrm{g} / \mathrm{g}$ oil; $\delta$-tocopherol $215 \mu \mathrm{g} / \mathrm{g}$ oil) (Table 4). Tocotrienols were not present in any of the botanical tissues.

\section{Cytotoxicity in HepG2 Line}

For cell viability analysis, HepG2 cells were exposed to different concentrations of both extracts during 24 or $48 \mathrm{~h}$; cell viability was analyzed immediately after each exposure and also after a 24 -h recovery period. The results of multiple comparisons (classified according to the Tukey's test or Tamhane's T2 test, depending on the homoscedasticity criterion) are shown in
Figures 1 and 2. To avoid biased outcomes, results regarding positive control were not included in correlation analysis, as they might mask possible differences among the assayed concentrations. In most cases, the values for cell viability showed statistical differences, especially those obtained when cells were exposed to the highest concentrations of the extracts.

Results obtained in the MTT assay after $24 \mathrm{~h}$ exposure to stems and leaves extracts (Figure 1A) displayed a significant concentration-dependent decrease in viability, either in cells allowed to recover for a 24-h period, as in those assayed immediately after exposure. Using the same conditions employing the NRU assay (Figure 1B), which provides information regarding cell lysosomal activity, results also demonstrated a significant concentration-dependent decrease in viability. Considering the 48-h exposure of stems and leaves extracts, the findings were similar. The reduction in cell viability was also found to be concentration dependent in MTT assay. Once again, the induced cytotoxicity seemed to be irreversible (Figure 1C). Regarding the NRU assay (Figure 1D), cells
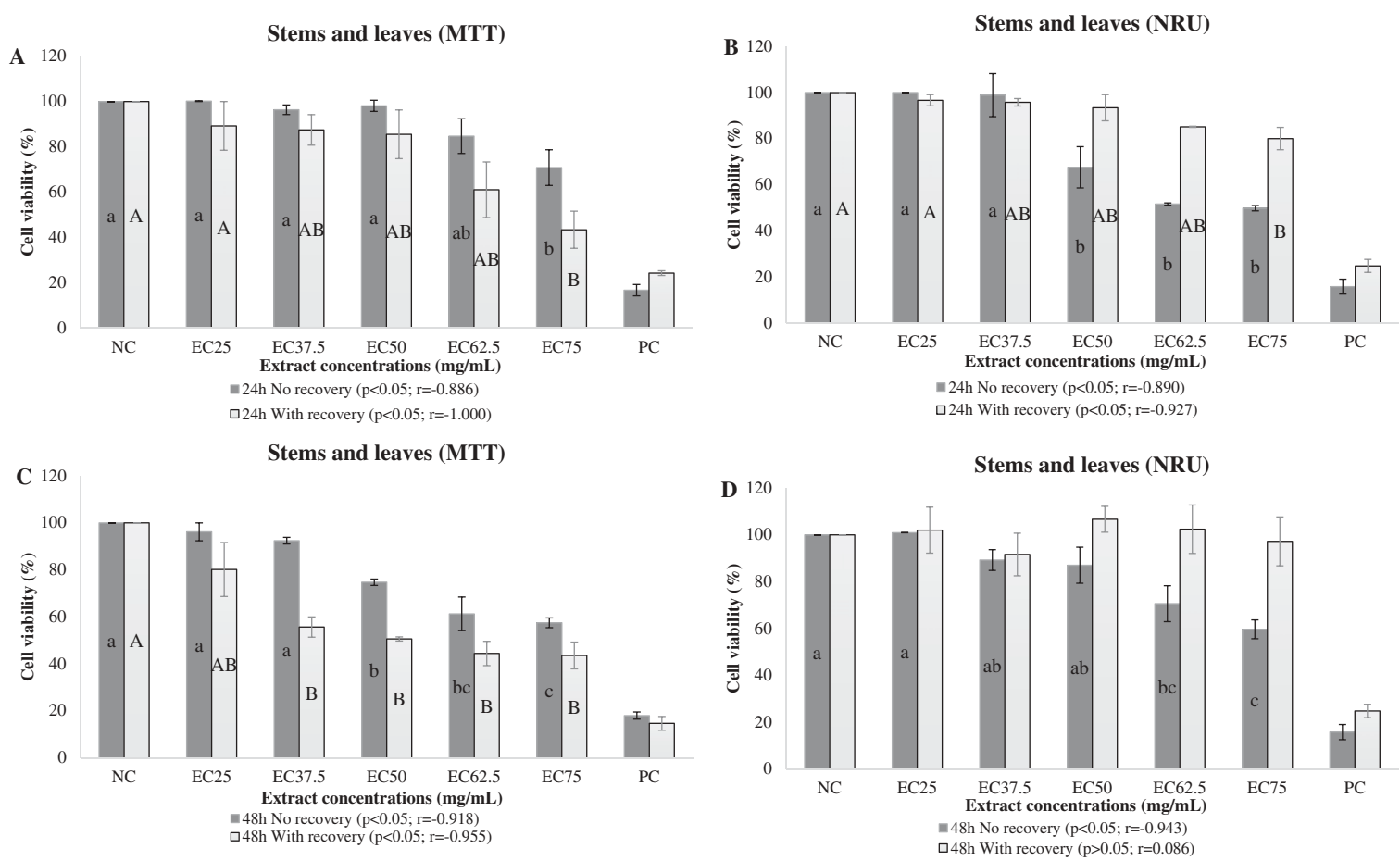

Figure 1. Cell viability for different stems and leaves extract concentrations. (A) $24 \mathrm{~h}$ exposure MTT assay; (B) $24 \mathrm{~h}$ exposure NRU assay; (C) $48 \mathrm{~h}$ exposure MTT assay; (D) $48 \mathrm{~h}$ exposure NRU assay. In all cases, results obtained immediately after exposure and after a 24-h recovery period are compared. NC: negative control (culture medium). PC: positive control (Triton X-100, 1\%). Different lower case letters in bars indicate statistically significant differences in cell viability without recovery; different capital letters in bars indicate statistically significant differences in cell viability with recovery. 

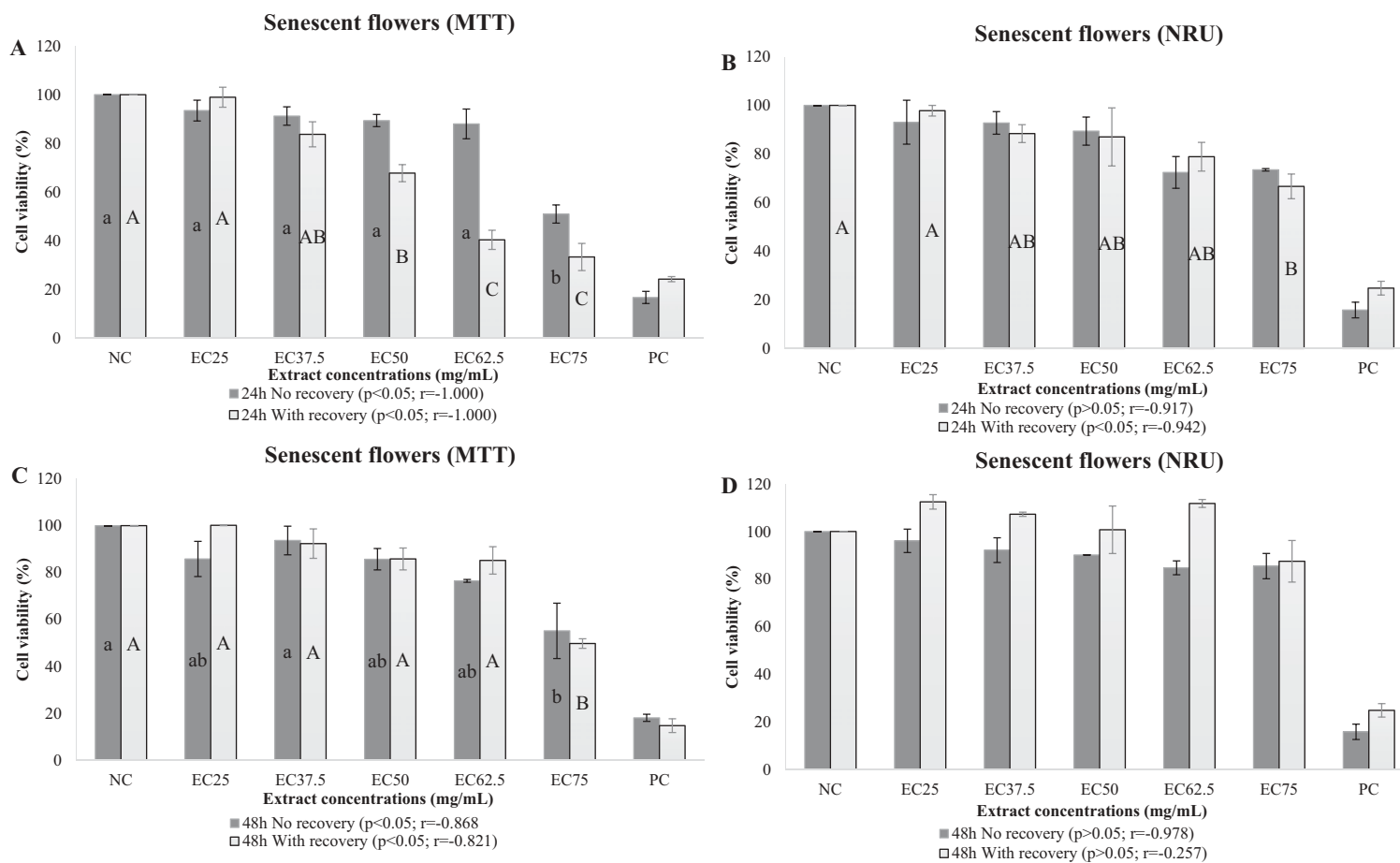

Figure 2. Cell viability for different senescent flowers extract concentrations. (A) $24 \mathrm{~h}$ exposure MTT assay; (B) $24 \mathrm{~h}$ exposure NRU assay; (C) $48 \mathrm{~h}$ exposure MTT assay; (D) $48 \mathrm{~h}$ exposure NRU assay. In all cases, results obtained immediately after exposure and after a 24-h recovery period are compared. NC: negative control (culture medium). PC: positive control (Triton X-100, 1\%). Different lower case letters in bars indicate statistically significant differences in cell viability without recovery; different capital letters in bars indicate statistically significant differences in cell viability with recovery.

assayed immediately after exposure were noted to display diminished viability in a concentrationdependent manner. Nevertheless, the reversibility status of the lysosomal damage induced in stems and leaves was confirmed in this case without showing a concentration-dependent effect, i.e., cells recover full viability independently of the extract concentration to which they were exposed.

Considering the senescent flower extracts (Figure 2), the $24 \mathrm{~h}$ exposure led to a significant concentration-dependent decrease in viability in MTT and NRU assays. Cells were not able to recover their mitochondrial or lysosomal activity after the 24-h-cell recovery period, since viability was found to be either lower (MTT) or similar (NRU) to the one observed immediately after exposure.

Data obtained for the 48-h exposure period were similar to those after $24 \mathrm{~h}$ in the MTT assay (Figure 2C). In addition, the concentration-dependent reduction in cell viability, cells could not recover from mitochondrial damage. The damage induced after $48 \mathrm{~h}$, when assayed immediately after exposure, was also concentration dependent. However, there was an evident recovery effect in the NRU assay (Figure 2D), as indicated by the similar cellular viability independent of extract concentration.

\section{Discussion}

\section{Nutritional and Chemical Composition}

Considering the macronutrients profiles, data were similar to those reported in other Asteraceae family plants (García-Herrera et al., 2014). Since there are no apparent available results for this species, no further comparison was performed. The energy values $(359 \mathrm{kcal} / 100 \mathrm{~g} \mathrm{dm}$ in stems and leaves and $370 \mathrm{kcal} / 100 \mathrm{~g} \mathrm{dm}$ in senescent flowers) correspond to nearly $15 \%$ (man) and $18 \%$ (woman) of the energetic daily dietary requirement (DDR). From a nutritional point of view, characterization of amino acid profile also deserves special attention, since these molecules are the building blocks of proteins. EAA, in particular, play important roles in several metabolic 
pathways, mostly as precursors of important physiologic compounds, besides participating in protein synthesis and turnover (Wu, 2009).

Besides being an essential proteinogenic amino acid, threonine has the particularity of being the only one, besides serine, presenting an alcohol group in the side chain (note that tyrosine is not considered as an alcohol, but as a phenol, since the $\mathrm{OH}$ group in the side chain is linked to an aromatic ring, conferring different oxidative, and acid-base properties). Threonine is mainly involved in protein synthesis related to mucin which is necessary for intestinal integrity and function, but this amino acid exerts immunological functions and is a glycine precursor, which makes it useful to act as prodrug to elevate glycine levels in the brain (Stryer et al., 2002; Wu, 2009). The values detected for threonine content $15 \mathrm{mg} / \mathrm{g}$ $\mathrm{dm}$ in senescent flowers and $6.2 \mathrm{mg} / \mathrm{g} \mathrm{dm}$ in stems and leaves correspond to approximately 150\% (senescent flowers) and 60\% (stems and leaves) of its DDR, considering that $100 \mathrm{~g}$ of dried plant which is beyond the expected daily consumed dose. It is noteworthy that the values quantified for co-eluting aspartate and glutamate also include the contribution of asparagine and glutamine. Indeed, asparagine and glutamine are converted (the amide group in the side chain is converted into a carboxylic group) in their acidic forms (aspartate and glutamate) during acid hydrolysis. The high levels of lysine found in both botanical tissues increase the potential applications of $C$. myconis, since lysine is a first-line growth modulator, in addition to being a collagen constituent and an important carrier of FA (Fürst, 2009; Suárez-Belloch et al., 2015).

With respect to the FA profile, unsaturated FA/saturated fatty acids ratio scored 2.1 for senescent flowers and 4.6 for stems and leaves, increasing the nutritional potential value of $C$. myconis as a food ingredient, which is further enhanced by the predominance of omega- 3 and omega-6 FA. In fact, these FA were reported as exerting important health effects such as prevention of cardiovascular diseases and lowering related risk factors, anticarcinogenic activity, anti-inflammatory effect, growth promoters, and contribution to bone development (Yang et al., 2015).
Finally, the detected tocopherols levels, despite representing a small \% of DDR for vitamin $\mathrm{E}$ which is usually indicated as $10-15 \mathrm{mg} / \mathrm{d}$, might be considered as relevant, especially for disease prevention effects related to the high antioxidant activity. In atherosclerosis and related diseases, tocopherols exert their effect through inhibiting lipid peroxidation and platelet aggregation, while reducing the anti-inflammatory response (Mathur et al., 2015).

\section{Cytotoxicity Evaluation}

Concerning stems and leaves, data obtained in the MTT assay after both exposure periods (24 and 48 h) showed that cell viability continued to diminish even after extract removal and replacement by fresh medium, indicating a nonreversible cytotoxic activity. On the other hand, in the case of the NRU assay conducted under the same conditions, cell-recovery data suggest that lysosomal damage mediated by stems and leaves extract is reversible, as cell viability was found to be higher than that observed immediately after exposure. Further, in the case of the 48$\mathrm{h}$ exposure period, cellular viability recovery was independent of extract concentrations.

In the case of senescent flowers, HepG2 cells were not able to recover from the mitochondrial and lysosomal damage suffered during the 24-h exposure period. However, when exposed for 48 h, HepG2 cells recovered from the lysosomal damage. Therefore, data demonstrated lower cell viability using the MTT compared to NRU assay, suggesting that mitochondria are particularly sensitive to C. myconis extracts.

Comparing the effects of the assayed botanical parts, the extracts obtained from stems and leaves displayed higher viability of HepG2 cells as evidenced by the $\mathrm{IC}_{50}$ values obtained in each case except for the NRU assay following $48 \mathrm{~h}$ incubation. In the MTT assay performed with stems and leaves extracts, the obtained $\mathrm{IC}_{50}$ values were 1.07 $\mathrm{mg} / \mathrm{ml}(24 \mathrm{~h})$ and $0.95 \mathrm{mg} / \mathrm{ml}(48 \mathrm{~h})$, while the values in senescent flowers were $0.3 \mathrm{mg} / \mathrm{ml}(24 \mathrm{~h})$ and $0.35 \mathrm{mg} / \mathrm{ml}(48 \mathrm{~h})$. In the NRU assay, the calculated $\mathrm{IC}_{50}$ values were $0.82 \mathrm{mg} / \mathrm{ml}(24 \mathrm{~h})$ and $1.02 \mathrm{mg} / \mathrm{ml}(48 \mathrm{~h})$ for stems and leaves extracts and $0.48 \mathrm{mg} / \mathrm{ml}(24 \mathrm{~h})$ and $1.13 \mathrm{mg} / \mathrm{ml}$ $(48 \mathrm{~h})$ for senescent flowers extracts threonine. 


\section{Principal Components Analysis}

PCA was applied to determine the parameters (simultaneously including all variables corresponding to chemical profiles and cytotoxicity evaluation) that best characterize each of the assayed C. myconis botanical tissues, in order to obtain a better definition of their potential applications. The plot of object scores and component loadings (Figure 3) indicated that the first two dimensions were significant (first: Cronbach's $\alpha, 0.998$; eigenvalue, 41.562; second: Cronbach's $\alpha, 0.063$; eigenvalue, 1.066), accounting for most of the variance $(94.8 \%)$ of all quantified variables (first: $92.94 \%$; second: $2.4 \%$ ). The clusters corresponding to each botanical tissue (green parts and senescent flowers) were clearly separated, mainly due to the contribution of dimension 1 . From the represented biplot, it became apparent that the green parts are mainly characterized by higher levels in carbohydrates, PUFA (especially C18:3n3), tocopherols (except $\beta$ - and $\gamma$-tocopherol), and lower cytotoxicity against HepG2 cells, with particular relevance in the MTT assay (for both exposure times) and in the 24-h incubation of the NRU assay. On the other hand, senescent flowers are mainly typified by their higher levels of water, fat, protein, amino

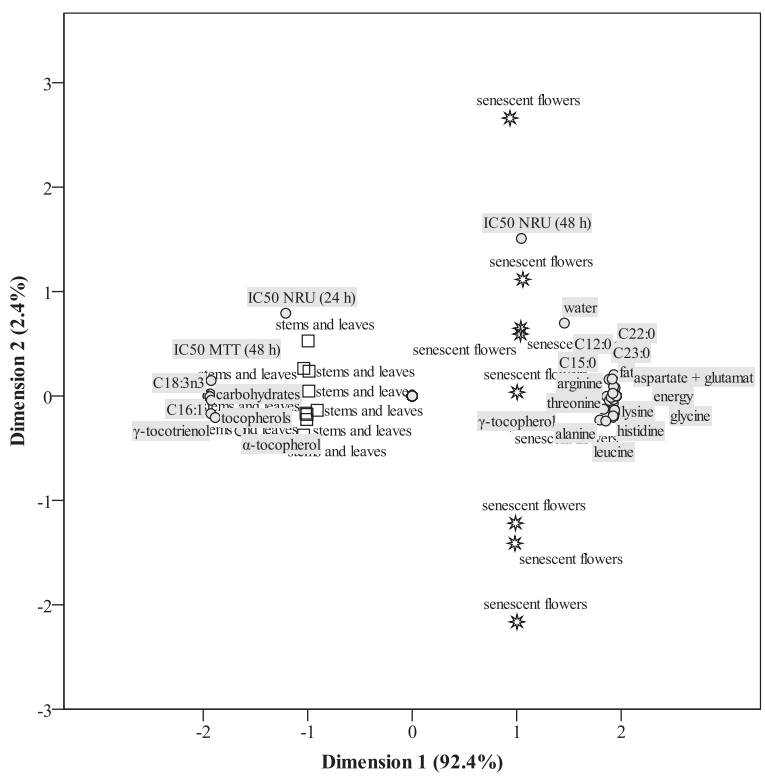

Figure 3. Biplot of object (plant parts) scores and component loadings (evaluated parameters). The first two dimensions defined from the principal components obtained by orthogonal transformation of the original variables are plotted, as well as the variance percentage explained by each of them. acids, and MUFA (especially C18:1n9c) and lower cytotoxicity as measured by the NRU assay conducted in cells exposed for $48 \mathrm{~h}$.

\section{Conclusions}

Considering macronutrients profile, amino acids, and lipophilic compounds (FA, tocopherols), $C$. myconis may be considered as a wild plant with high interest for incorporation in functional foods or food supplements. The assayed botanical parts exhibited complementary chemical and cytotoxic profiles, thereby raising the possibility of being used in diverse applications. Further, mitochondrial (MTT assay) and lysosomal (NRU assay) damage were only significant when exposing HepG2 cells to the extract concentrations corresponding to the $\mathrm{EC}_{75}$ for both botanical tissues, indicating a potential safe use without presenting acute toxicity risks.

\section{Funding}

The authors are grateful to the Foundation for Science and Technology (FCT, Portugal) for financial support to REQUIMTE (PEst-C/EQB/LA0006/2014) and to CIMO (UID/AGR/00690/2013). J.C.M. Barreira, Carla Costa, and Filipa B. Pimentel thank FCT, POPH-QREN, and FSE for their grants (SFRH/BPD/72802/2010, SFRH/BPD/96196/2013 and SFRH/BD/109042/2015, respectively).

\section{References}

AOAC. 2012. "Official methods of analysis of AOAC International." 19th ed. edited by W. Horwitz, Gaithersburg, USA.

Atwater, W. O., and Benedict, F. G. 1902. Experiments on the metabolism of matter and energy in the human body, 1898-1900. Washington, DC: US Office of Experiment Stations Bulletin No. 109, Government Printing Office.

Bernal, J., Mendiola, J. A., Ibáñez, E., and Cifuentes, A. 2011. Advanced analysis of nutraceuticals. J. Pharm. Biomed. Anal. 55: 758-774.

Bessada, S. M. F., Barreira, J. C. M., Barros, L., Ferreira, I. C. F. R., and Oliveira, M. B. P. P. 2016. Phenolic profile and antioxidant activity of Coleostephus myconis (L.) Rchb.f.: An underexploited and highly disseminated species. Ind. Crop. Prod. 89: 45-51.

Bessada, S. M. F., Barreira, J. C. M., and Oliveira, M. B. P. P. 2015. Asteraceae species with most prominent bioactivity and their potential applications: A review. Ind. Crop. Prod. 76: 604-615. 
Borenfreund, E., and Puerner, J. A. 1985. Toxicity determined in vitro by morphological alterations and neutral red absorption. Toxicol. Lett. 24: 119-124.

Commission Regulation (2002) . No. 796/2002 of.6 May 2002 amending Regulation (EEC) No. 2568/91. OJ L 128 (pp. 0008-0028.).

Dias, M. I., Barros, L., Alves, R. C., Oliveira, M. B. P. P., Santos-Buelga, C., and Ferreira, I. C. F. R. 2014. Nutritional composition, antioxidant activity and phenolic compounds of wild Taraxacum sect. ruderalia. Food Res. Int. 56: 266-271.

Franco, E. S., Mélo, M. E., Militão, G. C., Rocha, R. E., Silva, L. T., Jatobá, B. J., Silva, P. B., Santana, A. L., Silva, A. A., Silva, T. G., Nascimento, M. S., and Maia, M. B. 2015. Evaluation of the acute toxicity, cytotoxicity, and genotoxicity of Chresta martii (Asteraceae). J. Toxicol. Environ. Health A 78: 1083-1093.

Fürst, P. 2009. Basics in clinical nutrition: Proteins and amino acids. Eur. J. Clin. Nutr. Metab. 4: e62-e65.

García-Herrera, P., Sánchez-Mata, M. C., Cámara. M., Fernández-Ruiz, V., Díez-Marqués, C., Molina, M., and Tardío, J. 2014. Nutrient composition of six wild edible Mediterranean Asteraceae plants of dietary interest. J. Food Composit. Anal. 34: 163-170.

Ju, S. M., Jang, H. J., Kim, K. B., and Kim, J. 2015. Highthroughput cytotoxicity testing system of acetaminophen using a microfluidic device (MFD) in HepG2 cells. J. Toxicol. Environ. Health A 78: 1063-1072.
Krishnaiah, D., Rosalam, S., and Rajesh, N. 2011. A review of the antioxidant potential of medicinal plant species. Food Bioprod. Process. 89: 217-233.

Mathur, P., Ding, Z., Saldeen, T., and Mehta, J. L. 2015. Tocopherols in the prevention and treatment of atherosclerosis and related cardiovascular disease. Clin. Cardiol. 38: $570-576$.

Mosmann, T. 1983. Rapid colorimetric assay for cellular growth and survival: Application to proliferation and cytotoxicity assays. J. Immunol. Meth. 65: 55-63.

Rodrigues, F., Santos, J., Pimentel, F. B., Braga, N., Palmeirade-Oliveira, A., and Oliveira, M. B. P. P. 2015. Promising new applications of Castanea sativa shell: Nutritional composition, antioxidant activity, amino acids and vitamin $\mathrm{E}$ profile. Food Funct. 6: 2854-2860.

Stryer, L., Berg, J. M., and Tymoczko, J. L. 2002. Biochemistry: International Edition. New York: W. H. Freeman \& Co Ltd; 5th revised edition.

Suárez-Belloch, J., Guada, J. A., and Latorre, M. A. 2015. The effect of lysine restriction during grower period on productive performance, serum metabolites and fatness of heavy barrows and gilts. Livest. Sci. 171: 36-43.

Wu, G. 2009. Amino acids: metabolism, functions, and nutrition. Amino Acids 37: 1-17.

Yang, B., Chen, H., Stanton, C., Ross, R. P., Zhang, H., Chen, Y. Q., and Chen, W. 2015. Review of the roles of conjugated linoleic acid in health and disease. J. Funct. Food. 15: 314-325. 